\title{
Redesign or demise of old Developmental States? East Asia in the post-financial crisis of 2008
}

\author{
Redesenho ou extinção dos antigos Estados em Desenvolvimento? \\ O Leste Asiático no pós-crise financeira de 2008
}

ROBERTA RODRIGUES MARQUES DA SILVA *

RAFAEL SHOENMANN DE MOURA **,+,++,

RESUMO: Este artigo investiga comparativamente a dinâmica recente de desenvolvimento de quatro economias políticas do Leste Asiático: Japão, Coreia do Sul, Taiwan e China. Analisamos como a conjuntura crítica gerada pela crise sistêmica do subprime dos EUA afetou suas capacidades estatais; particularmente em relação à política industrial, sendo mediada pelos respectivos marcos regulatórios e institucionais. Além disso, comparamos os impactos da crise de 2008 e da anterior crise regional asiática de 1997. Nossas descobertas indicam que as capacidades do Estado, associadas à construção histórica de um Estado em Desenvolvimento, foram um recurso central para entender a resiliência de cada economia política.

PALAVRAS-CHAVE: Leste Asiático; capacidades do Estado; crise financeira; conjuntura crítica.

ABSTRACT: This article investigates comparatively the recent developmental dynamics of four East Asian political economies: Japan, South Korea, Taiwan and China. We analyze how the critical juncture engendered by the systemic crisis of the US subprime impacted on its State capabilities, particularly regarding industrial policy, being mediated by the respective regulatory and institutional frameworks. Additionally, we compare the impacts of the 2008 crisis and the previous Asian regional crisis of 1997. Our findings indicate that

\footnotetext{
* Adjunct Professor, Department of Political Science, Universidade Federal Fluminense - UFF, Rio de Janeiro/RJ, Brasil. E-mail: roberta.rms@gmail.com. Orcid: https://orcid.org/0000-0001-5015-5922.

** Institute of Social and Political Studies of the State University of Rio de Janeiro (IESP-UERJ), Rio de Janeiro/RJ, Brasil. E-mail: rafaelmoura5028@gmail.com. Orcid: https://orcid.org/0000-0003-4185-4005. Submitted: 6/February/2019; Approved: 19/December/2019.

$+\mathrm{PhD}$ in Political Science; Assistant secretary of the Latin-American Association of Political Science (ALACIP).

++ The authors would like to deeply thank Professors Marcus Ianoni, Renato Raul Boschi and anonymous peer reviewers, for their careful readings, comments and critical remarks. Co-author Rafael Moura would also like to thank Professor Luiz Fernando de Paula for his patience and teachings, and the research groups of NEIC (Núcleo de Estudos do Empresariado, Instituições e Capitalismo) and GEEP (Grupo de Estudos de Economia e Política) for continued support and relevant discussions.
} 
State capabilities, associated to the historical construction of a Developmental State, were a central feature to understand the resilience of each political economy.

KEYWORDS: east asia; state Capabilities; Financial Crisis; Critical Juncture.

JEL Classification: O1; O5.

\section{INTRODUCTION}

This article seeks to map recent changes and nuances in the developmental trajectories of four selected East Asian political economies: China, Japan, South Korea and Taiwan, analyzing their resilience in face of both the 2008 US subprime crisis and the 1997 Asian financial crisis. The rationale employed for choosing these national cases is threefold: 1 ) they are the four largest economies in the region. ${ }^{1}$ 2) They were able to successfully achieve technological catching-up through strongly interventionist States and public authorities on the economic realm, with relatively insulated bureaucracies emphasizing exports of manufactures (Moura, 2017). And 3 ), due to the region's historical idiosyncrasy of witnessing two major crises in a short time frame (in 1997 and 2008), distinct in their natures and proportions but both product of a wave of deregulations and acceleration of cross-border financial flows (Pempel \& Tsunekawa, 2015).

Throughout this reflection, three concepts will be particularly important: 1) State capabilities: the skill of the political actors and bureaucrats of national States to identify distributive conflicts associated to the development strategy adopted and equate them within coordinated directives, thereby promoting structural and qualitative economic transformations (Evans, 1993). 2) Critical junctures: such junctures represent transitions or turning points reorienting completely political and economic trajectories, establishing new societal cleavages or legacies permeated by "path dependence" (Collier \& Collier, 1991; Pierson, 2004). They correspond to a concatenation of endogenous and/or exogenous factors disrupting a previous pattern established in society (Acemoglu \& Robinson, 2012, p.79-80). 3) Developmental States: productive modernizations that these countries went throughout the second half of the XXth century, with their States achieving the status of authentic "substitute-entrepreneurs" by promoting discretionary and selective industrial policies in order to coordinate profound changes (Chang, 1999; Johnson, 1999; Moura, 2017).

We argue that the countries that most resisted the dismantling or decentralization of the institutional and regulatory legacies of their Developmental States were

\footnotetext{
${ }^{1}$ In 2016, their economies registered a Gross Domestic Product (GDP) of approximately 11.200, 4.940, 1.411 and 530 billion dollars, respectively (World Bank, 2018; Trading Economics, 2018). It is noteworthy that Hong Kong and Singapore, large economies occasionally included as analytical cases in comparisons involving East Asia, were discarded because of their particular configurations as CityStates.
} 
the most resilient to recent financial crises. Japan and South Korea, that underwent more radical neoliberal reforms, were in turn the most vulnerable to both episodes.

It is worth noting that the selected countries' development strategies varied in terms of content - which industrial policies were privileged at early stages of development trajectory - and time - when development policies were implemented. However, the four selected political economies are frequently considered in the literature as similar cases (Chang, 2006) or even connected to one another (Palma, 2004), being presented as successful development experiences. Following path dependency arguments, we highlight that decisions taken at early stages of an institutional trajectory may produce lock-in effects, i.e.,, particular institutional features produce positive feedbacks and remain over time (Pierson, 2004). In this sense, specific State capabilities - not only central government bureaucratic planning bodies, but especially rigid financial and/or banking regulations -, pivotal to launching successful industrial policies at early times, remain important to the present day as focal points that enable adequate responses to international financial crises.

In the following section, we will make a historical recapitulation of the late industrializing spur experienced by these countries over the second half of the last century. Within the theoretical light of the ideal type of the Developmental State, we will highlight the main political, economic and institutional elements responsible for the success of these East Asian nations in their logics of insertion in the international division of labor and global value chains. In the third section, our focus will be on the Asian crisis of 1997, contextualized under the prism both of the changes in vogue in the international economy and of the domestic transformations that these countries went through, in terms of their macroeconomic foundations. In the fourth section, we will analyze the 2008 financial crisis in the United States and the spread of its impacts on the regional productive dynamics of Asia. Afterwards, still in the same section, we will immerse ourselves in a historicalcomparative exercise, contrasting the current crisis with that of 1997 in the region, drawing similarities and discrepancies between the two junctures to map out continuities or overcoming of structural vulnerabilities in these productive regimes. The last section will present the final considerations.

\section{EAST ASIAN DEVELOPMENTAL STATES IN THE XXth CENTURY: HISTORICAL PATHS AND SUCCESSFUL ELEMENTS OF LATE INDUSTRIALIZATION}

The so-called Developmental State is a theoretical-historical paradigm taken as indispensable condition for explaining industrialization, urbanization and qualitative socioeconomic transformations of the late coming countries in the international division of labor; inspiring a robust literature focused on the actual experiences of several countries, particularly in East Asia (Johnson, 1982; Amsden, 1989; Wade, 1990; Evans, 1993; Chang, 2006). Chang (1999) abstracts and lists the main common points found throughout this literature. According to the author, they are: 
a) An autochthonous and deliberate national strategy of development headed by the State and aiming to coordinate changes on a large scale, always within the framework of a market economy and logic of capital accumulation;

b) Provision by the State of an entrepreneurial vision, with government organs being responsible for planning and not being resigned to the mere correction of asymmetries and "market failures", but rather designating the most profitable niches to boost the earnings of certain sectors in accordance with the previously mentioned strategy. In doing so, it created a more attractive menu of choices to the bourgeoisie or national entrepreneurs;

c) Institutional building, establishing the regulatory framework most conducive to strengthening certain markets and their economies of scale;

d) Equation of political conflicts; with the government acting directly towards the creation of institutions providing the dilution and distribution of risks between corporate and civil society actors.

Thus, in late-coming industrializing countries, rather than merely providing an "adequate" business environment, the State actively ingested, created and organized the market, assuming emerging risks along the path (Evans, 1993).

In reference to East Asia in particular, Chalmers Johnson (1982) was the first author to employ the concept of "Developmental State" to deal with a country of the region, in case the rebuilt Japan and its modern and discretionary industrial policy from the decade of 1950 onwards. His intention, departing from a detailed study of the paradigmatic policies advanced by the bureaucracy of MITI (Ministry of International Trade and Industry), particularly under the government of Shigeru Yoshida, was to focus on the country's institutional specificities and complementarities in order to map the "success formula" responsible for designing its economy and its large industrial conglomerates (keiretsus).

Subsequently, the application of such ideal type was extended to other experiences in the region, such as Taiwan under the Guomindang (KMT) and South Korea under the military government of Park Chung-Hee (Wade, 1990; Chang, 2006). All these nations - and also China few decades later - overcame adverse conditions and entered a virtuous development path with high rates of gross capital formation, denser industrial parks and productive chains, wage and export growth, becoming truly competitive manufacturing hubs on global scale.

Japan, Taiwan, and South Korea were the most consecrated regional cases of this institutionalist literature throughout the 1980s. They were the most notable processes of insertion in the capitalist interstate system after World War II, with institutional designs guided by the active and central role of public authority in terms of economic decision-making.

The World Bank issued a study in 1993 in which attempted, though strong emphasis on the "good macroeconomic fundamentals", to unravel the details and particularities of this intense process of capital accumulation and growth achieved by the countries of the region, with high productive investments, poverty reduction and acquisition/transfer of technologies from abroad (World Bank, 1993). In the report, launched in the wake of financial globalization and hegemony of the 
Washington Consensus, and which portrayed the "Four Asian Tigers" together with Japan, Indonesia, Malaysia and Thailand, the most striking feature was the fact that such countries, particularly the so-called "Northeast Asian" cluster (Japan and the first-tier NICS - Newly Industrialized Countries), were successful in catching-up thanks to a degree of discretion over private initiative clearly contrary to what the institution itself recommended to developing countries (Chang, 2006). ${ }^{2}$

Industrial policy proved cohesive in terms of obtaining commitment of the economic and political elites to the goals established by the decision-making bureaucracy, with the State promoting import substitution, reverse engineering, selective tariff protectionism, joint ventures for foreign technology transfers and scale gains so that nascent companies could find favorable conditions for exports. They thus overcame both external constraints to the balance of payments and the reduced scope of their domestic markets (except for China and Japan), limited by policies to restrict consumption and by the growth of domestic wages below the productivity rates (Chang, 2006).

Another factor ensuring to its companies more competitiveness in international markets was the maintenance of devalued and favorable exchange rates, possible due to foreign exchange controls. Such governments, operating commonly within centralized, insulated and/or authoritarian political regimes, thus, shielded national economies from the volatilities arising from capital flows, potentially conducive to speculative crises and monetary instabilities, in addition to the inexorable negative consequences for national sovereignty (Johnson, 1999; Chang, 2006; Moura, 2017).

This was feasible only due to the specific conditions to which their respective financial sectors were subjected. In Japan, during the 1950s, MITI bureaucrats acquired control over virtually all foreign currencies; fostering governmental institutions like the Japan Development Bank (JDB or Kaigin) which controlled huge resources and indicative powers for policy loans. The Japanese industrial system also had the generalized practice of firms incurring in systematical borrowing from JDB and/or other commercial banks, which in turn resorted to the Bank of Japan for capital and credit availability (Johnson, 1982, chap. 6).

In South Korea, shortly after the military coup that brought him to power in 1961, Park nationalized the entire national banking sector - that started operating in a logic almost analogous to public companies - and the country's capital stock, formerly in the hands of rentiers and speculators; in addition to restricting voting rights of most private shareholders. Thus, by consolidating such regulations, it was able to systematically mobilize domestic and foreign capital to foster selective strategic sectors of domestic industry through credit channelling (Yoo, 2006).

In Taiwan, between the 1950s and 1970s, the KMT government also intervened in the financial system by instrumentalizing interest rates for allocation of

\footnotetext{
${ }^{2}$ They are: Singapore, South Korea, Hong Kong and Taiwan.
} 
funds according to priority targets, and also transferring resources from individual consumers to corporate investors (Wade, 1990).

The Chinese domestic financial system is no exception to such observed patterns, and it has too a strong degree of government intervention and concentration in large public banks, with its national banking sector being one of the most regulated segments of the economy and highly protected from external competition (Naughton, 2007; Cintra \& Silva Filho, 2015; Jabbour \& Paula, 2018). ${ }^{3}$ It is characterized by Naughton (2007, p.449-452) as a "deep and narrow" sector, in the sense of holding an increasing volume of financial assets in proportion to the total national income while not having so many institutions and instruments for intermediation of resources, elucidating as capital markets are still relatively closed. Through the course of opening-up reforms, this system has proven to be a fundamental pillar for mobilizing China's high domestic savings - derived primarily from household deposits - for productive investments (mainly in infrastructure) through politically connected large State conglomerates, semi-private or private firms (Naughton, 2007; Cintra \& Silva Filho, 2015). ${ }^{4}$

Hence, direct or indirect public control of banking systems - albeit with varying degrees of intensity - was the prime lever for financing industrial coordination in all the cases of political economies analyzed here. These configurations of regulatory regimes were also result, in some extent (at least for Japan, Korea and Taiwan), of the specific context of the Cold War in the region, with capital flights being quite salient due to recurrent geopolitical tensions; making the accumulation of reserves via primary surpluses and strategic use of incoming resources even more imperative.

Regarding China specifically, it is undeniable that it holds a unique legacy of a planned political economy regime that endured for almost three decades. Under such historical time frame, a program of heavy industrialization centered on capital goods and metallurgy was put into practice, motivated by the logic of defense against possible threats derived from the Cold War, mainly after the Sino-Soviet rupture occurred in the turn of the 1950s to the 1960s (Naughton, 2007). Set, on one side, in an agricultural surplus extraction structure from the communes to the urban coast, and, on the other, in self-sufficient manufacturing clusters, China went

\footnotetext{
${ }^{3}$ This "State-dominated financial system" (Cintra \& Silva Filho, 2015, p.440) is hegemonized by five large commercial banks (Agricultural Bank of China; Bank of China; China Construction Bank; Industrial and Commercial Bank of China; and China Bank of Communications) and three large development and policy banks: China Development Bank (CDB), Agricultural Development Bank of China (ADBC) and, finally, the Ex-Im Bank of China.

${ }^{4}$ In the wake of this discussion, we point out that the lending of domestic credit to the Chinese private sector by banks jumps from $65,3 \%$ of the GDP in 1985 to an impressive rate of $157 \%$ in 2017, on an almost uninterrupted upward trajectory over more than three decades. Such credit has proved indispensable for the country to achieve very high investment rates over the period, with gross fixed capital formation also rising from $28 \%$ of the GDP in 1977 to $40 \%$ in recent years (World Bank, 2018).
} 
through profound social transformations starting in 1978, changing its productive axis and being reintegrated by Deng Xiaoping to the global economy becoming a colossal producer and exporter pole of light consumer goods (Naughton, 2007; Nolan, 2013)..$^{5}$

Particularly in the 1990s, under the government of Jiang Zemin (1993-2003), the Chinese government created new institutions that further resembled the country from the classic cases of the Asian regional neighbours. Besides the creation of the three development and policy banks previously mentioned (fn.11) in 1994, in the second half of the decade the government adopted a restructuring and strategic repositioning of the public and private sectors that formally gave a formal birth to what can be understood as the China's policy of national champions (Nolan, 2013). Galvanized by the orientation "Grasp the large, release the small" (zhuada fangxiao - 抓大放小), emphasized in the fourth plenary section of the 15th Congress of the CPC, Chinese authorities moved forward a broad productive restructuring focusing on large public conglomerates in key sectors (Table 1) constituting the "core" of the economy, seeking to raise the productive structure for more capitalintensive goods and new technologies (Nolan, 2013). ${ }^{6}$ This strategic relaunch of State action was one of the many institutional innovations witnessed along the trajectory of China's political economy and it expanded the government's planning abilities to socialize investment (Jabbour \& Paula, 2018).

From the moment that the post-transition Chinese experience shares the same predicates used in the categorization thus far of the Developmental State, with substitutive policies, capital controls, compulsory joint ventures between domestic and transnational firms, discretionary price controls, and active use of public development banks, there would be no reason to exclude it from such conceptual employment (Jabbour \& Dantas, 2017; Moura, 2017).

Thus, having pointed the main elements regarding the evolution of the productive structures of these countries, the next section of the article will turn to the analysis of the causes of the Asian regional financial crisis of 1997 and how it relates to the undergoing changes that these economies were passing through during that decade, as well as its unfolding and the governmental responses to it.

\footnotetext{
${ }^{5}$ And, subsequently, products of higher added value.

${ }^{6}$ Thus, despite the privatization of many sectors over that decade, this trend alone is insufficient to account for the complexity of all political processes throughout Jiang Zemin's government (Nolan, 2013). The commanding heights of the economy remained publicly owned and the Party remained, through the Organization Department of its Central Committee, strictly able to point the leaderships and high hierarchies of such conglomerates. Subsequently, the State-Owned Assets Supervision and Administration Commission (SASAC, founded in 2003) will assume direct control over the financial assets of this chain of firms.
} 


\section{REVISITING THE 1997 REGIONAL FINANCIAL COLLAPSE: A REAPPRAISAL}

Mainly from the 1990s onwards, the developmentalist models adopted by East Asian countries, centered on the strong presence of the State inducing economic growth, were increasingly pressured by external and domestic forces, seeking further liberalization and deregulation of their product and financial markets. These pressures reached an extremely high level when these countries - in particular South Korea - were affected by the financial and foreign exchange crisis in 1997, which undermined in some extent their virtuous trajectories of catching up promotion.

On the international front, financial globalization, the new unilateral order brought by the end of the Cold War and the expansion of the neoliberal ideology from Washington moved forward growing structural constraints on development paradigms alternative to the liberal variety of capitalism, including the East Asian Developmental States (Hall \& Soskice, 2001; Torres Filho, 2014).

At the domestic level, despite the diversity of experiences regarding State-society relations, we consider paradigmatic for instance the case of South Korea, where the very success of the development model contradictorily led to the weakening of State interventionism in the economy. South Korean business conglomerates - the chaebols - have grown to the point where, mainly since the Roh Tae Woo's government (1988-1993), they have modified the bargaining pendulum with the State in their favor; capitulating to neoliberalism and dismantling the previous institutional system with its traditional long-term investment coordination mechanisms. This trend was not only circumscribed to the Korean case but was also present, to lesser or greater extent, in the other concerned countries of East Asia with the exception of China. Through their own articulation in the complex dynamics of the global productive chains, domestic firms became increasingly "disembedded" from the instrumental imperatives of domestic governments and national economies, showing how in several cases the Developmental State became a "victim of its own success" (Yeung, 2016, p.22).

As result, the country adopted, from late 1980s to the 1990s, measures aimed at loosening controls over capital inflows and outflows, besides a broad privatization program in the public banking sector (Chang, 2006; Okabe, 2015).

In the 1990s, South Korea's liberalizing trajectory was reinvigorated with civilian president Kim Young Sam (1993-1998), who promoted: deregulation of interest rates; expansion of banks' managerial autonomy; lower entry barriers for financial activities; restriction of credit lines for specific industrial sectors; liberalization of the exchange rate and greater openness of the stock market for foreign investors (Kang, 2000; Chang, 2006; Okabe, 2015). It also dissolved the famous Economic Planning Board (EPB), technobureaucratic body responsible for formulating the country's five-year plans. This was precisely the pivot of the subsequent end of the financial containment and mobilization process in favor of South Korean industry (Lechevalier et al., 2017, p.18).

In a Polanyian sense, the South Korean State was - just like the Japanese, as 
we shall see - the premium mobile of the neoliberal shift, acting through public institutions for the recapitalization of insolvent financial sectors via organs such as the Korea Asset Management Corporation and the Korea Deposit Insurance Corporation (Lechevalier et al., 2017). With the Bank of Korea Act in 1999, a pro-finance economic policy was definitively institutionalized: monetary stability now was the major goal recommended for the central bank authorities' pursuit, in line with the neoliberal monetarist vision. The shareholders' interests were thus privileged vis-à-vis the industrialists, reversing the hegemonic State-finance nexus; also delegitimizing the strong pro-growth and pro-investment intervenient policy that was remarkable in its post-war productive regime until the 1990s (Chang, 2006; Lechevalier et al., 2017).

The 1997 financial crisis imposed several challenges on the pro-market reforms being adopted, to a greater or lesser extent, by the different countries of East and Southeast Asia. Having as background the devaluation of the baht (Thai currency), it spread among second-tier NICs such as Malaysia and Indonesia; also affecting several stock markets such as South Korea's, and provoking an economic recession in a first generation NIC that had a GDP and per capita income much higher visà-vis other countries of the continent's southeast (Krugman, 2009).

Clearly, the crisis did not spread throughout the region due to excessive government interventions, "bad macroeconomic fundamentals" or proliferation of "moral hazards", but rather by uncoordinated private sector investments financed by reckless and excessive short-term external debt, made possible only because of the same financial liberalization of capital account previously mentioned (Chang, 2006).

In the case of Japan, the analysis is particularly relevant because the country was the pioneer reference - in terms of State action and management-labor relations - for other nations of the region and also by the fact that, at that time, it was the largest Asian power being the core of that capitalist block; with a developmentalist and industrialist model based on massive investments and manufacture exports that allowed it to successfully escape from the middle-income trap (Tsunekawa, 2015). It should be noted, however, that when the crisis broke out the country was already in the midst of a severe recession and stagnation due to the burst of the national speculative bubble at the beginning of the decade, whose origins in turn date back to the 1980 s.

This "early" financial liberalization, in turn, led to drastic changes in the environment faced by the industrial policy pursued by the Japanese government, mainly by the prime ministers Suzuki Zenko (1980-1982) and Nakasone Yasuhiro (1982-1987), both of the Liberal Democratic Party (LDP), the same responsible for the catching- up (Lechevalier et al., 2017). Both presidents, through administrative reforms seeking to balance the national budget and remedy the fiscal crisis of the country, pursued a liberalizing agenda facilitating, among other things, the transnationalization of Japanese firms and a dismantling movement of labour protective laws, that would continue over the following years (Itoh, 2005).

Also, the reform of the administrative structure in wake of the liberalizing wave decentralized and fragmented industrial policy among different ministries, with a 
subsequent emptying of attributes of the MITI (Lechevalier et al., 2017). This set of measures represented the erosion of established practices and institutions that facilitated the coordination of interests between market and government (Tsunekawa, 2015; Lechevalier et al., 2017).

In the 1990s, the continuity of such neoliberal policies weakened previous developmental orientations, provoking a decline of the corporatist support base of the dominant conservative party (LDP). The US pressures from the Washington Consensus in favor of such policy line, even after the severe economic conditions of the bubble burst, contributed to a rhetoric blaming these same institutions for such problems, under the pretext that they were costly for new investments (Tsunekawa, 2015).

With the government of Ryutaro Hashimoto (1996-1998), there was an attempt to give cohesion and systematicity to reforms aiming at fiscal discipline and austerity through institutional restructuring, exemplified by the Fiscal Structural Reform Act (1997). When the Asian crisis broke out in 1998, the political forces behind such attempt found a window of opportunities to demand an even larger contingency of welfare and pension programs as an additional part of the menu of policies. If the episode of the 1998 Asian regional crisis has not caused the economic problems of a Japan already plunged in volatilities and insolvency of the domestic financial sector, it certainly aggravated the magnitude of its recession (Tsunekawa, 2015). On the opposite, the crisis served as an additional rhetoric for the Japanese political forces in government to internalize the private debt and reduce social policies as a supposedly "necessary" response to market dysfunctions (Lechevalier et al., 2017).

In a comparative perspective, it is possible to state that Taiwan was, alongside China, one of the least affected countries by the Asian regional crisis of 1997-1998 among those analyzed here. ${ }^{7}$ During the first half of the 1990s Taiwan was completing its political reform institutionalizing a representative democracy and its party system, a formal process that had begun in the 1980s under Chiang Ching-Kuo (Chiang Kai-Shek's son) with the lifting of the Martial Law in 1987. This new erected system would be divided mainly between the forces of KMT and the newly founded Democratic Party Progressive (DPP). It is interesting to note that Taiwan illustrates a case where the democratization was more driven by issues of ethnic character than by class demands from the new diversified industrial society, byproduct of its own economic success (Rigger, 1999). ${ }^{8}$

After the episode, however, the Taiwanese State lost much of the coherence in

\footnotetext{
${ }^{7}$ In the following years, the country kept growing economically with GDP annual rates near 5\% (contrary to Japan and Korea which underwent recession), being the second least one affected in terms of productive performance - only behind China.

${ }^{8}$ Besides the repression of the KMT regime, there was also another important factor impacting on the low level of mobilization and political organization of the working class: the very particularity of the Taiwanese national industrial structure that was its segmentation in small firms (employing less than 30 workers), which in the 1980 s comprised $80 \%$ of the waged workforce (Minns, 2006).
} 
its ideological orientation to promote a new pro-development pact, although its "dismantling" of the Developmental State's legacy had been gradual and carefully managed; making it still in the mid-1990s imbued with important macroeconomic management tools that allowed it to withstand the external shock of the 1997-1998 crisis (Minns, 2006). ${ }^{9}$

A clear example of this slow dismantling of state capabilities is Lee Teng-hui's (1988-2000) erratic liberalization program during that decade: after the establishment of an ambitious goal foreseeing the privatization of 122 public firms in 1989 at the start of his term, only six effectively became private in 1997; in the midst of corporatist resistances of internal segments of KMT. On the regulatory realm, however, it is imperative to note that the conservative Taiwanese Central Bank maintained heavy restrictions on the debt base of private banks and financial institutions, contributing to a certain degree to shield the national economy (Minns, 2006, p.228-229).

If, on one hand, the crisis did not bring bankruptcy or abrupt recession, on the other hand it led to an important political change that was the election of President Chen Shui-biang of the Democratic Progressive Party (DPP), after more than fifty years of the KMT rule. With neoliberal economic orientation and now operating within the constitutional framework of a democratized and more decentralized political system, Chen's government acutely reduced the political protagonism of state-owned firms, which greatly undermined the strategic sense of Taiwanese industrial policy (Chu, 2015).

With clear focus on the financial sector, the DPP pressed the authorities of the country's central bank throughout the 2000s to loosen existing regulatory frameworks - which have insulated the island from volatilities for decades in the midst of globalization - in order to allow a higher quota for institutional shareholders on capital markets. Hence, just before the outbreak of the 2008 crisis, foreign share was already exceeding more than $25 \%$ of the total capitalization of the domestic market (Chu, 2015).

Finally, the impacts of the regional crisis in China were also not so severe in terms of national coverage. Exactly because it did not have an open capital account, the contagion on the country was residual, occurring mainly through Hong Kong that was highly interconnected to the Pearl River Delta region and channelled foreign financial flows to municipal and local governments of the most "capitalist" and internationally integrated province of China, Guangdong (Nolan, 2013; Naughton, 2015).

With the country undergoing domestic macroeconomic problems such as the State-owned enterprises' reform led by Jiang Zemin and slightly more uncomfort-

\footnotetext{
${ }^{9}$ To this loss of coherence contributed the fact that, since the abandonment of "democratic centralism" as a constitutional clause in 1988 and the relaxation of the political system, the KMT has become increasingly decentralized and fragmented into local factions with different interests and demands. Thus, the very redefinition of a consistent national development strategy was hampered.
} 
able inflation rates, the outbreak of the Asian regional crisis led indirectly to the insolvency of rural credit cooperatives and non-bank financial institutions such as GDE (Guangdong Enterprises) and GITIC (Guangdong International Trust and Investment Corporation), both owned by the local government. This, at first, raised risks regarding a possible wider liquidity crisis (Nolan, 2013).

The Communist Party of China (CPC) and the Chinese government authorities, however, were quite effective in overcoming such issues. As Nolan points out (2013: p.33), three major direct responses were given to the crisis: a) the initial permit to GITIC's bankruptcy, in order to avoid the spreading of "moral hazard"; $b$ ) the restructuring of GDE; and c) a series of recapitalizations and reforms of more than 800 non-bank financial institutions. All these steps were taken in order to mitigate the direct and indirect effects of the Asian crisis on the Chinese productive and social fabric, as well as on its own financial system, even though it was - as previously described in Section II - quite "closed" in comparative terms and with a predominance of State control of most assets and credit (Moura, 2015).

Another responsive measure to the episode, even if indirectly and to a lesser extent, was the launching of the China Western Development Program in 1999. The strategy was initially proposed by Jiang in March at the National People's Congress (NPC) and later converted into a government strategy later that year. The program ushered new internal dynamics of growth emphasizing energy and transport infrastructures, with strong links in heavy industry and a focus on urbanization in the inner country (Jabbour \& Paula, 2018). The goal was to stimulate consumption and domestic demand for a historically not-favored area within Chinese development (more focused on coastal areas), given the impacts of the external crisis that made exports virtually stagnate between 1997 and 1998 (Lai, 2002).

The interpretations of the Asian regional crisis differ, concentrating on two antagonistic perspectives: for affiliates more closer to neoclassical and liberal thinking, the episode resulted from the still excessive presence of the State in the economy, which maintained non-market ties - therefore biased - with private sector, favoring corruption and establishing a "crony capitalism" (Frankel, 1998). On the other hand, economists of different strands - critical institutionalists, developmentalists, Keynesians - considered that the Asian collapse was consequence of the very policies of capital account liberalization and deregulation adopted since the end of the 1980s, integrating these countries with the global financial markets, subjecting them to speculative movements and panic of financial investors (Chang, 2000). When the crisis broke out in Thailand, investors failed to distinguish between emerging countries that actually had different economic fundamentals and reduced levels of trade and even financial relations (Krugman, 2009).

An overview of this section points clearly that the first interpretation listed in the above paragraph - of liberals and neoclassicals - finds no corroboration in these four historical trajectories. Undoubtedly, many of the developmentalist and industrializing orientations followed contained their particular contradictions and structural problems. However, it is not possible to establish any clear and convincing causal link about public interventionism regarding the crisis or the magnitude of 
its impact. China and Taiwan, for example, two countries that did not undergo liberalizing financial reforms or opening up of capital accounts for foreign investors were precisely the most resilient in terms of adverse socioeconomic impacts. Japan and South Korea, in turn, were negatively affected precisely according to the degree of intensity of their neoliberal institutional restructurings.

It should also be remembered that the IMF, supported by the United States' Treasury, granted bail-out packages to the Asian countries affected by the crisis; demanding, in return, that their governments would carry out structural reforms allowing an even greater deepening of liberalization of their markets, as well as austere economic policies centered on high interest rates and public spending cuts, which eventually postponed economic recovery (Krugman, 2009; Stiglitz, 2010). The IMF completely ignored the particularities of the different Asian economies affected by the financial crisis, prescribing the same recipe for very different countries.

Unlike the perspective of the economic mainstream, which conceives financial crises as exogenous shocks that affects the equilibrium of markets freely conducted by private interests, the occurrence of those episodes is endogenous to capitalism, becoming frequent with the advent of financial globalization (Krugman, 2009). In this sense, the crises and volatilities in developing countries between 1994 (Mexico) and 2001 (Argentina) preceded and foreshadowed a major crisis, detonated in 2008 in the United States, epicenter of global financial capitalism. On this and the subsequent responses from East Asian countries, we will cover the next section.

\section{THE 2008 FINANCIAL CRISIS: SPREAD THROUGH THE ASIAN PRODUCTIVE CIRCUIT AND COMPARATIVE FORECASTS}

Financial crises are inherent to capitalism's nature, occurring from time to time in various parts of the global economy with different levels of contagion depending on circumstances (Kindleberger \& Aliber, 2011). However, they became more frequent from the turn of the 1970s to the 1980s, with the consolidation of the contemporary globalized financial system. Such new paradigm of capitalism, replacing the previous international economic order governed by the Keynesian monetary framework of Bretton Woods, was driven by institutional finance and deregulation of capital markets, with high propensity to generate financial (particularly foreign exchange) crises as it expanded territorially and brought new countries - or emerging markets - into its orbit (Torres Filho, 2014).

The most recent crisis, however, is distinctive in the sense that it did not break out on the global periphery but at its core, emanating from structural and institutional failures in the US financial market; which, through its own degree of interconnection with the other parts of the world, ended up having profound and direct impacts or unfolding on each region, acquiring a systemic character.

The analysis of the multifaceted current crisis should focus on the institutional and regulatory financial order structuring the behavior of economic agents. According to Blyth (2017, p.48-9), four generating devices stand out correlated: the market 
structure of "repo" operations; derivative securities backed by mortgages; the greater exposure of investment portfolios and, finally, the very ideological premises of bankers and regulators. All these elements were created, enhanced or exacerbated by the new economic architecture cited. Greater capital mobility, together with the scarce State and Interstate regulation of the newly created financial instruments, allowed the progressive leverage of these institutions and even of companies (Torres Filho, 2014; Blyth, 2017). The deregulation of financial markets, based on a neoliberal ideology advocating the allocative efficiency of "self-regulated" markets, allowed the formation of speculative bubbles more frequently, making countries around the world more vulnerable to the occurrence of such episodes (Stiglitz, 2010).

In this sense, the last crisis was also expression of a crisis of the prevailing neoliberal ideology, followed by a renewed debate on ideas and policy (Stiglitz, 2010; Blyth, 2017). According to Stiglitz (2010) from the point of view of the economic mainstream, the 2008 episode is seen as an "accident", resulting from actions of certain unscrupulous individuals occupying key positions in the financial markets, as well as, ironically, the regulatory deficiencies of the State, which had not created the necessary conditions for the correct functioning of the markets. For the heterodox interpretative key, the crisis occurred due to the low regulation of banking activities (Stiglitz, 2010) or the lack of an oversight and regulatory apparatus for investment banks over time (Krugman, 2009).

Despite the magnitude of the crisis, the first strand seems to have triumphed in the US political landscape, given that the Bush and Obama administrations adopted measures to socialize the losses of private agents, followed later by the political leaders of the Eurozone. Thus, the State internalized an eminently private debt and transferred it to the population through packages of austerity and redemption, with expansion of public indebtedness, fiscal retraction and dismantling of social and labour rights (Blyth, 2017).

We shall now turn to the radiography of the consequences of such episode in East Asia in particular, first by describing the impacts and responses of each individual country and then closing the section with a summary of the main elements and common trends and/or discrepancies.

Beginning with Japan, the global financial crisis (GFC) hit the country at a very precarious political moment for the LDP, shortly after DPJ's significant victory in the Legislative and additional stimulus on governance. Although Japanese exposure to US toxic financial derivatives and assets was not particularly high, especially in comparison with Europe, the economy was still impacted by the severe contraction in global trade (Tsunekawa, 2015). Moreover, the years following the crisis contributed to a period of stagnation and deceleration of demand in the international economy, imposing a considerable challenge to the Asian productive regimes; which, after decades of exports as one of the main drivers of growth, could no longer rely on the good momentum of world trade. Figures 1 and 2 below allow a more reliable view of this trend, with a slowdown in the growth of exports of these countries and in the share of foreign trade in their economies, in relative and absolute terms: 
Figure 1: Growth of Exports (\% per year) in Selected Countries

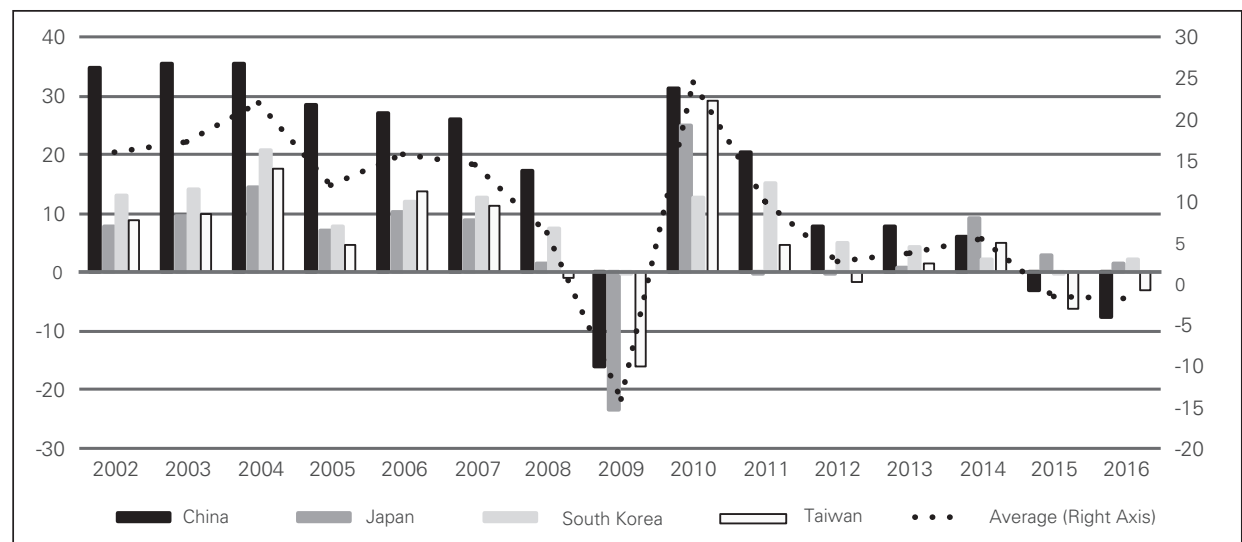

Sources: World Bank, World Development Indicators; Republic of China, Taiwan Statistical Data Book, 2017.

Figure 2: Share of exports in East Asia in relative (\% GDP) and absolute terms (US\$ trillions)

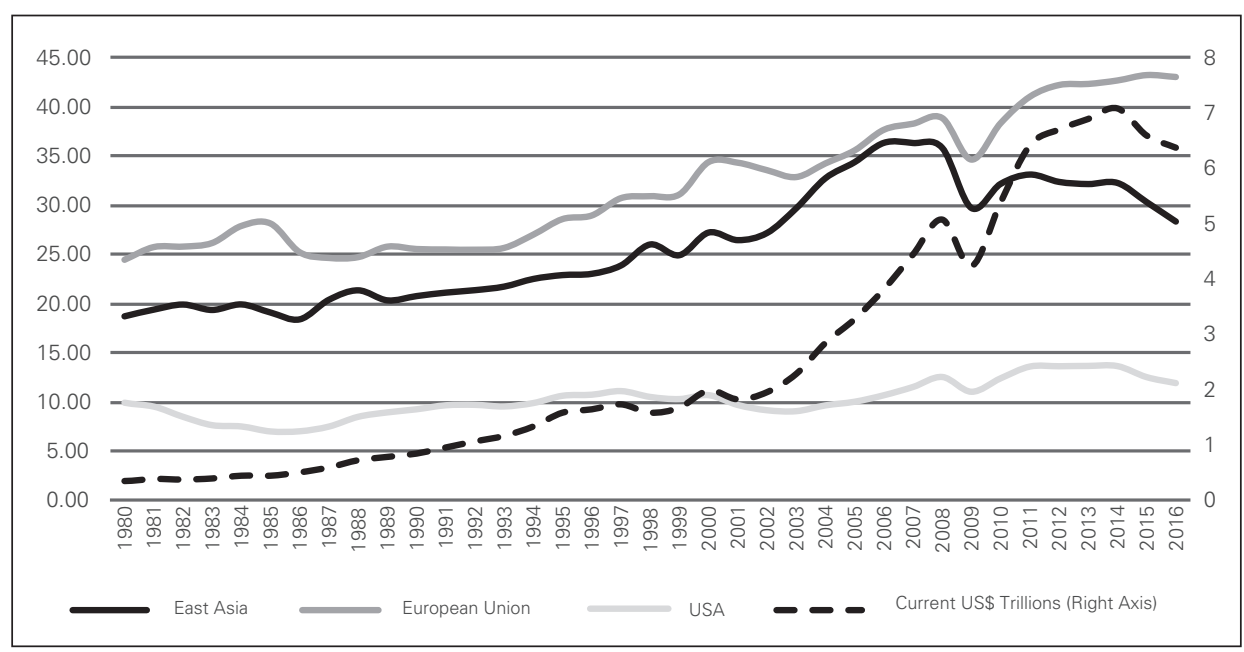

Sources: World Bank, World Development Indicators; Republic of China, Taiwan Statistical Data Book, 2017.

In the Japanese case, the best synthesis of the post-crisis scenario is the sharpening of pressures on public spending, especially in view of the efforts to increase social security spending concomitant with the increase in government debt from $140 \%$ to almost 200\% of GDP between 2008 and 2016 (Tsunekawa, 2015; World Bank, 2018). Between August 2008 and April 2009, during Yasuo Fukuda and Taro Aso administrations, the government tried to respond by relaxing fiscal discipline and resorted to public debt financing to make use of stimulus packages, totalling an amount of approximately 27.4 trillion yen (Tsunekawa, 2015).

Nevertheless, even the expansion of public spending was not enough to miti- 
gate the erosion of LDP's popularity, with the rise of a new political coalition - still in 2009 - now led by the Democratic Party of Japan (DPJ). This, on the other hand, failed either in reconfiguring the productive bases of the Japanese economy, and to recompose the fiscal margin of the State to engage in redistributive programs or foment improvement in the economic and labour scenario. This contributed to the fact that the Coalition erected by the DPJ, therefore, soon lost its majority in the House of Councilors in the July 2010 elections, despite still maintaining Prime Minister Naoto Kan.

The continuing inconsistency in Japanese policy directions has only been relatively remediated with Shinzo Abe's reemergence to power in 2012. Now with a clearer economic agenda openly prioritizing budget expansion through Quantitative Easings and other instruments, he attempted to improve social and well-being indicators in the post-crisis period. However, Abe's strategy of developing and resuming economic growth is mixed and contradictory, maintaining neoliberal elements, such as: reduction of corporate taxes; business and labor deregulation; reduction of life insurance; the engagement to Trans-Pacific Partnership/TPP; etc. (Tsunekawa, 2015). Within "Abemonics", however, also stand out some heterodox elements, such as its efforts to coordinate countercyclical policies by aligning fiscal, monetary, and exchange rate policies. The greatest example of this may be in its attempt to repeal the Organic Law of the Bank of Japan to force the country's Central Bank - which previously enjoyed formal "independence" - to relax its inflation targeting priority in order to submit it primarily to the goal fostering growth (Lechevalier et al., 2017).

In this sense, Abe shifted the monetary policy in a rather drastic sense in light of the latest Japanese decision-making patterns: a clear effort to expand State capabilities and discretion over the volume of credit to focus on government allocative targets. The new guidelines were: reduction of long-term interest rates to encourage productive activity in detriment of financial remuneration to the rentier; expansion of loans and investments for risk activities; and the already mentioned changed expectations for inflation (Lechevalier et al., 2017).

However, Abe's policies were insufficient for Japan to envisage a qualitatively different juncture from the one experienced of semi-stagnation, also presenting growing contradictions as its industrial policy proves ineffective in promoting national start-ups and overcoming the chronic problems of political articulation of goals in a competitive globalized economy (Lechevalier et al., 2017).

Regarding South Korea, ironically, part of the restructuring and institutional reforms set in motion after the Asian Regional Crisis (ARC), such as those of the national banking system, have increased - instead of diminishing - the country's vulnerability to the impact of the 2008 crisis (Okabe, 2015). The way in which the different consequences of this global financial crisis were processed domestically is therefore intrinsically linked to the intensification of the liberalizing process and deregulation that the country experienced in the interregnum between both episodes. The 1997 crisis was pivotal to transform definitely the old institutional complementarities inherited from the South Korean classical developmentalist 
paradigm and completely reverse the prevailing hierarchical State-finance nexus, inducing a change of this order and the empowerment of the rentier financial sector (Chang, 2006; Lechevalier et al., 2017). In this new scenario, Korean banks and foreign banks' branches in the country - gradually freer from insolvency - increased their lending volume over the years, with the ratio of loans to deposits increasing from $71 \%$ in 1998 to $92,8 \%$ in 2008 (Bank of Korea, 2019). Thus, to complement exactly this leverage of lending ratio to deposits, they often used interbank foreign resources (Okabe, 2015).

The 2000s also witnessed a boom in foreign portfolio investments in the country, amounting more than U\$ 50 billion in 2007. This was primarily due to two reasons: a) many Koreans shifted their assets to foreign investment funds and to capital markets because of low domestic interest rates; and $b$ ) still within the neoliberal wave described, the scope of tax exemptions on dividends of shares listed abroad only widened, mainly between 2007 and 2009. Consequently, there was an exorbitant increase in the dependence of short-term foreign resources on the economy by banks, which also used such amounts to hedge against exchange rate swings (Okabe, 2015).

Thus, the new national indebtedness profile, with gradual and excessive reliance on short-term foreign capital and loans, made both domestic banks and the branches of foreign banks even more vulnerable to liquidity and funding risks in the global economy, though not to American subprime assets directly. As an aggravating circumstance, both Kim Dae-jung's (1998-2003) and Roh Moo-hyun's (2003-2008) governments were extremely lenient with the ramifications of international banks based in the country. When the global financial crisis broke out in 2008, there was a colossal decline in capital inflows to the country, with the national currency suddenly depreciating over $30 \%$ and causing a considerable loss of international reserves over 60 billion dollars between 2007 and 2008 (World Bank, 2018).

Since 2008, the new government of Lee Myung-bak attempted to institute relatively more robust regulatory policies, establishing the Financial Services Commission instead of the former Financial Supervisory Commission (FSC). The task now imbued to the Central Bank of Korea (BOK) would be to stiffen supervision on institutions to avoid financial and balance of payments instabilities, besides being a liquidity provider. According to Okabe (2015), two reasons can be pointed out to explain why previous governments and the Ministry of Strategy and Finance did not consider the seriousness of excessive short-term debt: 1) government was permissive due to its own liberal ideology, which led its technocrats to believe that the banking sector had solid foundations after the 1997 reforms; and 2) the apparently quick recovery of Korean financial institutions shortly after the greater permissiveness of capital inflows and outflows led to a "statistical illusion", obliterating risks of the absence of rectification mechanisms by domestic regulatory agencies (2015: p.106). At the same time, the government also did not frame foreign banks regarding their foreign currency-based assets.

The institutional restructuring witnessed by South Korea with the deepening of neoliberalism after 1997 eventually encouraged Korean banks to borrow more 
from abroad, in stark contrast to the lethargy observed in some other Asian countries (such as China, Taiwan and Thailand) which eventually adopted more conservative stances in terms of lending - and that turned out to be positive (Pempel, 2015). On the other hand, the country's experience after 2008 also showed that "institutional rigidity" does not necessarily contribute to strengthen mechanisms against the volatilities engendered by the global flows of capitalism. On the contrary, it puts the national economy even more at risk when domestic regulators make misleading judgments about the behavior of financial market players (Chang, 2006; Okabe, 2015).

Our third case analyzed of Taiwan shares the same peculiar problem of Korea: the country was relatively more vulnerable to the crisis of 2008 than it was during the outbreak of the Asian regional crisis eleven years before (Chu, 2015). In Chu's view, perhaps the greatest facilitator of Taiwan's state capabilities to deal with the impacts of the most recent episode was externalist; in this case, the more cooperative regional interstate position in Asia and multilateral institutional arrangements introducing safeguards and important collective defense mechanisms (2015: p.85). To this end, contributed both the Guomindang (KMT) political initiatives to restore diplomatic and economic trust with China and the intensification of regional cooperation within the ASEAN + 3 bloc, notably through the Chiang Mai Multilateral Initiative and the Asian Securities Market Initiative (Chu, 2015; Pempel, 2015).

Domestically, the still high share of public banks in the national credit system also provided room for maneuver for the government to direct fiscal policy more easily. Adding this element to the return of the KMT to power in 2008 with President Ma Ying-Jeou, the government was able to reissue a more statist and corporatist political stance (Chu, 2015).

Thus, the fiscal margin at Ma's disposal was channelled in a Keynesian economic policy line to compensate for aggregate demand in order to meet four main goals: first, the direct use of financial institutions and government funds under public ownership to stabilize the bond market, ensuring funding mainly for small and medium enterprises; second, to stimulate investments and creation of jobs through public works via a package of 500 billion Taiwanese dollars; third, to stimulate household consumption via citizen vouchers; and finally, to direct incentives and subsidies to sectors capable of quickly absorbing labor, mitigating unemployment, boosting the resumption of exports and recovering the State's own tax base (Wang, 2010; Chu, 2015). These policies proved successful in rapidly reversing the adverse scenario caused by the financial crash, with occupancy levels returning to roughly the same pre-crisis levels.

There is also a last special mention of the existing "protective cushions": the exchange reserves accumulated by the country during the decade of 2000, during the term of the previous president Chen Shui-bian (DPP, 2000-2008), along with the low indebtedness were highly relevant to mitigate greater adverse economic 
impacts. ${ }^{10}$ In this sense, as mentioned in reference to South Korea, the conservative and institutionally rigid stance of Taiwan's banking sector proved to be one of the sources of its own resilience during the international financial crisis (Chu, 2015).

We now move to China, the last country here analyzed. The great Asian power, in absolute terms, was the one that gave the most compelling political and economic response to the global crisis among the countries of the region (Nolan, 2013; Naughton, 2015)..$^{11}$

The event found China in a largely favorable domestic position. This was possible due to four elements: the huge accumulation of reserves by the country throughout that decade, result of a successful commercial strategy obtaining trade surpluses and strict institutional controls on entry and exit of foreign exchange; the fiscal balance of the government; the ambitious program of recapitalization and reorganization of insolvent loans led by President Hu Jintao between 2003 and 2006; and finally, state control over the national banking sector, with very strong government intervention in channelling existing domestic credit to equalize productive bottlenecks and sectoral transfers of resources (Naughton, 2015; Moura, 2015; Paula \& Jabbour, 2016). ${ }^{12}$ Hence, with this margin of maneuver, in November 2008 the high echelons of the CPC's Politburo decided to announce a vigorous policy to stimulate investment: $12.5 \%$ of GDP in the amount of 4 trillion RMB (renminbi) or 586 billions of dollars. Such a stimulus program was heavily focused on the infrastructure and civil construction sectors, addressing deficiencies in China's own economy and also political demands of local and subnational governments (Naughton, 2015).

In short, it can be said that the US subprime financial crisis of 2008 served to definitively consolidate the Chinese rise as an economic superpower (Naughton, 2015). After the crisis, bureaucratic, corporate and institutional reforms of local governments were engendered, with central political authorities flexibilizing some of the existing oversight over firms to encourage such governments to expand their spending on development through new gross investment projects. As direct result of this policy, the so-called "investment platforms" were created and amplified (rongzi pingtai - 融资平台): subnational governments issued bonds to finance and raise funds, thus allowing more assertive industrial policy initiatives at the local level through interventionism and planning in emerging strategic industry segments such as high technology, with increasing shares in the exports (Moura, 2015). Subsequently, with the Government Work Report prepared by Premier Wen Jiabao in 2010, such policies were "nationalized" and acquired more medium and long-term

\footnotetext{
${ }^{10}$ Between 2001 and 2005, for example, the Taiwanese government recorded an average of US $\$ 26.952$ billion in reserves in its balance of payments (Republic of China; Taiwan Statistical Data Book 2017).

${ }^{11}$ In proportional terms to the economy (GDP), the Chinese stimulus package was superior to the US package itself, and had a larger range of sectors and productive activities contemplated (Naughton, 2015).

12 Between 2000 and 2014, foreign exchange reserves accumulated by the Asian country grew from 200 million to more than 3 trillion dollars; and domestic credit to the private sector jumped from $100 \%$ to above $140 \%$ of GDP, with much of this increase occurring in the post-crisis period (Moura, 2015; World Bank, World Development Indicators).
} 
connotations, equating markets with central planning and administrative resources, bringing to the fore particular elements of the own functioning of the Chinese political system (Naughton, 2015).

Finally, even though China has, in part due to the myriad of policies and measures highlighted so far, been left unharmed in terms of the relative level of employment and income, the crisis of 2008 proved to be central to shift its accumulation basis of the country's productive regime and its development strategy (Moura, 2015). After decades of growing industrial complexification and an external insertion strongly focused on exports of consumer goods, boosted by its admission to the WTO in 2001, now in the post-crisis years China faces a completely adverse international trade scenario, with the once beneficial globalizing cycle becoming a scenario of deep uncertainties (Jaguaribe, 2011). In this sense, the CPC faces a new crossroad where innovation policies are even more relevant. In line with such changes, Chinese officials themselves, formerly Hu Jintao and now Xi Jinping, manifest a deliberate intention to shift the China's growth drivers to domestic consumption and R\&D. They are, therefore, aligned with the consequences of an economic slowdown that practically compels the country to pursue a more sustainable model of political economy in terms of greater social inclusion and environmental balance (Aglietta \& Guo, 2013; Moura, 2015).

Throughout this section, we mapped the key responses - via stylized facts from the four biggest East Asian political economies to the 2008 systemic crisis. Notwithstanding, we made a parsimonious radiography on how its institutional trajectories and growth patterns - as well as government choices and policies (product of incumbent political coalitions) in each moment - influenced directly between the 1997 regional crisis and the recent one, shaping their development paths and explaining both successes and relative setbacks.

\section{CONCLUDING REMARKS}

In this article, we aimed to analyze the impacts of two great financial crises the 1997 Asian Crisis and the 2008 Global Financial Crisis - on the four greatest East Asian economies - China, Japan, South Korea and Taiwan. Throughout the article, we argued that the maintenance or not of state capabilities, associated to the historical construction of successful Developmental States, is an indispensable feature to understand the degree of resilience of each political economy under analysis. Countries that underwent more radical neoliberal and institutional deregulation reforms were the most vulnerable to both crises.

In order to sustain our argument, we reconstituted historically the major changes in the productive regimes of the four largest selected East Asian economies. We traced the successful ingredients of its catching-up and industrial modernization processes, as well as different adjustments and changes in such frameworks in virtue of a changing world economic landscape and also the waves of financial globalization that redesigned the global political economy from the 1980s onwards. 
An additional intention of the first sections of the paper was to break with the shallow liberal analytical perspective which antagonizes the public authority embedded in the national state and the private economic agents, components of the market. By moving away from such dichotomy, we see instead that the governmental activism - in different ways, even by the discrepant natures of the political elites' projects within each country - was central for coordinating and synergistically projecting domestic firms in value chains and most advanced productive niches productive of the state-of-the-art of industry, in turn feedbacking the structural sophistication of its political economies and manufacturing parks. And they were essential, once again, in the most compelling responses to the volatilities of cutbacks of both crises.

In view of the above elements, the third section made an interesting "counterpoint" to the second one in order to show how nations that embraced more vehemently and uncoordinated - in principle - the neoliberal ideological prescriptions of deregulation embodied in the Washington Consensus were the most severely impacted by the regional crisis in 1997. It is striking that the opening-up of capital accounts and admission of greater flows and foreign participation in South Korea and Japan proved decisive to the expansion of conduits and contagion effects of financial instabilities. China, with its "closed" financial system and majority public participation in control and channelling of credit and resources for investments; and Taiwan, with particularly tight monetary and regulatory policies, were the nations most able to protect themselves against such adverse effects. Beyond the mere spillovers of a crisis from the financial realm to the real/productive realm, such changes in the institutional framework also reflected the new modus operandi of capitalism at a world level where industrial policy was increasingly marginalized and lost space for the hegemony of finance.

For reasons of scope, it was impossible for us to exhaust here with the analytical depth desired all the dimensions and consequences of both crises, without considering their own causal vectors, extremely complex in themselves. Nonetheless, we believe that, from the point of view of our original intended goal of comparing consequences of both episodes on domestic political economies in the region, we have been successful in exposing the nuances and magnitude of the impacts in light of the restructurings that such countries underwent, circumscribing the responses of each and the political and economic developments during the course of the 2000s. We also show, in the fourth section, how the systemic crisis of 2008 presented impacts of a different nature from the previous turbulence, imposing a greater external restriction through the global recession and damaging which was once the main engine of East Asian growth and success: the exports of manufactured goods to developed and developing countries.

\section{REFERENCES}

Acemoglu, D. \& Robinson, J. (2012). Por que as Nações fracassam: As origens do poder, da prosperidade e da pobreza. Rio de Janeiro: Elsevier. 
Aglietta, M. \& Guo, B. (2013). China's Development: Capitalism and Empire. London: Routledge.

Amsden, A. (1989). Asia's Next Giant: South Korea and Late Industrialization. New York: Oxford University Press.

Bank of Korea (2019). Economic Statistics System. Available at: http://ecos.bok.or.kr/EIndex_en.jsp (accessed in 04/09/2019).

Blyth, M. (2017). Austeridade: A história de uma ideia perigosa. São Paulo: Autonomia Literária.

Chang, H-J. (1999). “The Economic Theory of the Developmental State”, In Woo-Cumings, M. (ed.). The Developmental State. Ithaca: Cornell University Press: 182-199.

Chang, H-J. (2000). “The Hazard of Moral Hazard: Untangling the Asian Crisis”. World Development, 28 (4): $775-788$.

Chang, H-J. (2006). The East Asian Development Experience: The Miracle, the Crisis and the Future. London: ZED Books.

Chu, Y-h. (2015). "Unraveling the Enigma of East Asian Economic Resiliency". In Pempel, T.J. \& Tsunekawa, K. (eds.). Two Crises, Different Outcomes: East Asia and Global Finance. Ithaca: Cornell University Press: 64-89.

Cintra, M. \& Silva Filho, E. (2015). “O Sistema Financeiro Chinês: A Grande Muralha”. In Cintra, M.; Silva Filho, E. \& Pinto, E. C. (orgs.). China em Transformação: Dimensões Econômicas e Geopolíticas do Desenvolvimento. Rio de Janeiro: IPEA: 425-490.

Collier, R.B. \& Collier, D. (1991). Shaping the Political Arena: Critical Junctures, the Labor Movement, and Regime Dynamics in Latin America. New Jersey: Princeton University Press.

Corsetti, G.; Pesenti, P. \& Roubini, N. (1999). "What caused the Asian currency and financial crisis?”. Japan and the World Economy, 11: 305-373.

Evans, P. (1993). “O Estado como problema e solução”. Lua Nova, 28, 106-156.

Frankel, J. (1998). "The Asian Model, the Miracle, the Crisis and the Fund”. Speech delivered at the U.S. International Trade Comission, April 16. Available at: https://sites.hks.harvard.edu/fs/ jfrankel/eacritc.pub.pdf.

Hall, P. \& Soskice, D. (2001). Varieties of Capitalism: The Institutional Foundations of Comparative Advantages. New York: Oxford University Press.

Itoh, M. (2005). “Assessing Neoliberalism in Japan”. In Saad-Filho, A. \& Johnston, D. (eds.). Neoliberalism: A Critical Reader. London: Pluto Press: 244-250.

Jabbour, E. \& Dantas, A. (2017). “The Political Economy of Reforms and the Present Chinese Transition”. Brazilian Journal of Political Economy, 37 (4): 789-807.

Jabbour, E. \& Paula, L. F. (2018). “A China e a 'Socialização do Investimento’: Uma abordagem Keynes-Gerschenkron-Rangel-Hirschman”. Revista de Economia Contemporânea, 22 (1): 1-23.

Jaguaribe, A. (2011). “China: estratégias de modernização alternativa”. Desenvolvimento em Debate, 2 (2): 39-49.

Johnson, C. (1982). MITI and the Japanese Miracle: The Growth of Industrial Policy, 1925-1975. California: Stanford University Press.

Johnson, C. (1999). “The Developmental State: Odyssey of a Concept”. In Woo-Cumings, M. (ed.). The Developmental State. Ithaca: Cornell University Press: 32-60.

Kindleberger, C. \& Aliber, R. (2011). Manias, Panics and Crashes: A History of Financial Crises. $6^{a}$ ed. Basingstoke: Palgrave Macmillan.

Krugman, P. (2009). A Crise de 2008 e a Economia da Depressão. Rio de Janeiro: Elsevier.

Lai, H. H. (2002). "China’s Western Development Program: Its Rationale, Implementation, and Prospects”. Modern China, 28 (4): 432-466.

Lechevalier, S.; Debanes, P. \& Shin, W. (2017). "Financialization and industrial policies in Japan and Korea: Evolving institutional complementarities and loss of state capabilities”. Structural Chang and Economic Dynamics, Forthcoming: 1-40.

Moura, R. (2015). “A desaceleração chinesa e o 'Novo Normal': implicações estruturais para a economia e o setor financeiro doméstico". Desenvolvimento em Debate, 3 (2): 79-109.

Moura, R. (2017). "A China no espelho do Leste Asiático - retomando reflexões sobre o Estado Desenvolvimentista”. Oikos, 16 (3): 71-85. 
Naughton, B. (2007). The Chinese Economy: Transitions and Growth. Cambridge: The MIT Press.

Naughton, B. (2015). "China and the Two Crises: From 1997 to 2009". In Pempel, T.J. \& Tsunekawa, K. (eds.). Two Crises, Different Outcomes: East Asia and Global Finance. Ithaca: Cornell University Press: 110-134.

Nolan, P. (2013). Re-balancing China: Essays on the Global Financial Crisis, Industrial Policy and International Relations. London: Anthem Press.

Okabe, Y. (2015). "Reacting to Financial Crises: Institutional Path Dependence in Korea and Thailand”. In Pempel, T.J. \& Tsunekawa, K. (eds.). Two Crises, Different Outcomes: East Asia and Global Finance. Ithaca: Cornell University Press: 90-109.

Palma, G. (2004). "Gansos voadores e patos vulneráveis: a diferença da liderança do Japão e dos Estados Unidos no desenvolvimento do Sudeste Asiático e da América Latina”. In Fiori, J. L. (Org.). O Poder Americano. Petrópolis: Vozes: 393-453.

Pempel, T.J. (2015). “Two Crises, Two Outcomes”. In Pempel, T.J. \& Tsunekawa, K. (eds.). Two Crises, Different Outcomes: East Asia and Global Finance. Ithaca: Cornell University Press: 17-38.

Pempel, T.J. \& Tsunekawa, K. (2015). “Crises, Corrections, and Challenges”. In Pempel, T.J. \& Tsunekawa, K. (eds.). Two Crises, Different Outcomes: East Asia and Global Finance. Ithaca: Cornell University Press: 1-16.

Pierson, P. (2004). Politics in Time. History, Institutions and Social Analysis. Princeton and Oxford: Princeton University Press.

Republic of China. (2018). Taiwan Statistical Data Book 2017. Available at: https://www.ndc.gov.tw/ en/News_Content.aspx?n=607ED34345641980\&sms=B8A915763E3684AC\&s=1897C8025B0 899A0 (accessed in 15/04/2018).

Rigger, S. (1999). Politics in Taiwan: voting for democracy. London: Routledge.

Stiglitz, J. (2010). O mundo em queda livre: Os Estados Unidos, o mercado livre e o naufrágio da economía mundial. São Paulo: Cia das Letras.

Torres Filho, E. (2014). “A crise do sistema financeiro globalizado contemporâneo”. Revista de Economia Política, 34 (3): 433-450.

Trading Economics. (2018). Taiwan GDP Data Chart. Available at: https://tradingeconomics.com/ taiwan/gdp (accessed in 12/04/2018).

Tsunekawa, K. (2015). “Japan: The Political Economy of Long Stagnation”. In Pempel, T.J. \& Tsunekawa, K. (eds.). Two Crises, Different Outcomes: East Asia and Global Finance. Ithaca: Cornell University Press: $185-215$.

Wade, R. (1990). Governing the Market: Economic Theory and the Role of Government in East Asian Industrialization. New Jersey: Princeton University Press.

Wang, J-C. (2010). "The strategies adopted by Taiwan in response to the global financial crisis, and Taiwan's role in Asia-Pacific economic integration”. Japan and the World Economy, 22: 254-263.

World Bank. (1993). The East Asian Miracle: Economic Growth and Public Policy. New York: Oxford University Press.

World Bank. (2018). World Development Indicators. Available at: http://databank.worldbank.org/data/ reports.aspx? source=world-development-indicators (accessed in 12/04/2018).

World Bank. (2019). China Overview. Available at: https://www.worldbank.org/en/country/china/ overview (acessed in 30/08/2019).

Yeung, H. (2016). Strategic Coupling: East Asian Industrial Transformation in the New Global Economy. Ithaca: Cornell University Press.

Yoo, C-g. (2006). "Political and Institutional Conditions of Financial Repression”. In Lee, B-c. (ed.). Developmental Dictatorship and the Park Chung-hee Era: The Shaping of Modernity in the Republic of Korea. New Jersey: Homa \& Sekey Books: 134-152. 